\title{
A FILOSOFIA “OBRIGATÓRIA": PAULO FREIRE, GRAMSCI E A LEI 11684/2008
}

\author{
Reinaldo Ramos da Silva'
}

RESUMO: O objetivo deste artigo é o de relacionar, em perspectiva crítica, os conceitos de "filosofia espontânea" em Antonio Gramsci e de "pedagogia libertadora" (ou da autonomia) em Paulo Freire com os limites e possibilidades da Filosofia enquanto disciplina escolar a partir dos marcos legislativos que regulamentam seu ensino, considerando as aproximações e distanciamentos entre as diretrizes preconizadas pelo texto legal e a prática docente segundo as especificidades deste campo do saber, tomando como parâmetro a Lei federal de número 11684/2008 que institui sua introdução no rol de disciplinas obrigatórias da grade curricular das escolas de nível secundário, em suas três séries, em todo o país.

PALAVRAS-CHAVE: Ensino de Filosofia; Filosofia Espontânea; Pedagogia Libertadora; Pedagogia da Autonomia; Lei $11684 / 2008$.

ABSTRACT: The aim of this paper is to relate into a critical perspective the concepts of "spontaneous philosophy" in Antonio Gramsci and the "pedagogy of freedom" or 
"pedagogy of autonomy" in Paulo Freire with the limits and possibilities of Philosophy as a school subject since the legal frameworks that regulates its teaching process, considering the approaches and distances between the law text and the classroom practice according to the specificities of this knowledge field, holding the parameter of the federal law of number 11684/2008 which determinates its introduction in the group of mandatory disciplines of the Brazilian secondary school system.

KEYWORDS: Teaching Philosophy; Spontaneous Philosophy; Pedagogy of Freedom/'Pedagogy of Autonomy; Brazilian federal law no $11684 / 2008$. 
A Lei de Diretrizes de Bases da Educação de 1996 não regulamentava o ensino das disciplinas de Filosofia e Sociologia. Seu artigo de $n^{\circ} 36$ apenas indicava que o estudante ao término do ensino médio pudesse "demonstrar" ter o "domínio dos conhecimentos de Sociologia e Filosofia", atrelados à noção de "exercício da cidadania", sem desenvolver os meios pelos quais se promoveria a consecução deste objetivo. Foi a própria imprecisão do texto que deu azo para a regulamentação. O marco legal de certa maneira parecia já haver sido "desenhado", de maneira a preparar as condições para um posterior reordenamento curricular com a reintrodução das duas disciplinas, como nos mostra o texto do referido artigo:

O currículo do ensino médio observará o disposto na Seção I deste Capítulo e as seguintes diretrizes:

(...)

$\S 1^{\circ}$ Os conteúdos, as metodologias e as formas de avaliação serão organizados de tal forma que ao final do ensino médio o educando demonstre:

(...)

III - domínio dos conhecimentos de Filosofia e de Sociologia necessários ao exercício da cidadania.

A Câmara de Educação Básica aprovou parecer e resolução que tratam da inclusão obrigatória das disciplinas de Filosofia e Sociologia no currículo do Ensino Médio a partir do parecer CNE/CEB no 38/2006, aprovado em 7 de julho de 2006, que, dentre outras coisas, afirmava: 
Para garantia do cumprimento da diretriz da LDB, referente à Filosofia e à Sociologia, não há dúvida de que, qualquer que seja o tratamento dado a esses componentes, as escolas devem oferecer condições reais para sua efetivação, com professores habilitados em licenciaturas que concedam direito de docência desses componentes, além de outras condições, como, notadamente, acervo pertinente nas suas bibliotecas. (Parecer CNE/CEB nº 38/2006).

Também subsidiaram a alteração da LDB que tornaram as duas disciplinas componentes curriculares obrigatórios nos três anos do ensino médio nas redes pública e privada a Resolução CNE/CEB no 4, de 16 de agosto de 2006, que alterou o artigo 10 da Resolução CNE/CEB no 3/98, que institui as Diretrizes Curriculares Nacionais para o Ensino Médio, o Parecer CNE/CEB no 22/2008, aprovado em 8 de outubro de 2008 e a Resolução CNE/CEB no 1 , de 18 de maio de 2009. O Parecer CNE/CEB no 22/2008 destaca: "Nesta oportunidade, pode-se acrescentar que as escolas devem definir claramente o papel desses componentes no seu currículo, destinando carga horária suficiente para o seu adequado desenvolvimento".

Resolução CNE/CEB no ${ }^{\circ}$, de 18 de maio de 2009 dispunha, em seu primeiro artigo, que

Os componentes curriculares Filosofia e Sociologia se tornavam obrigatórios ao longo de todos os anos do Ensino Médio, qualquer que seja a denominação e a organização do currículo, estruturado este por sequência de séries ou não, composto por disciplinas ou por outras formas flexíveis. 
Em seu artigo segundo estabelecia que:

Os sistemas de ensino deverão estabelecer normas complementares e medidas concretas visando à inclusão dos componentes curriculares Filosofia e Sociologia em todas as escolas, públicas e privadas, obedecendo aos seguintes prazos de implantação:

I - início em 2009, com a inclusão obrigatória dos componentes curriculares Filosofia e Sociologia em, pelo menos, um dos anos do Ensino Médio, preferentemente a partir do primeiro ano do curso;

II - prosseguimento dessa inclusão ano a ano, até 2011, para os cursos de Ensino Médio com 3 (três) anos de duração, e até 2012, para os cursos com duração de 4 (quatro) anos.

Retiramos e destacamos os trechos acima das resoluções e pareceres para demonstrar o caráter abrangente e inédito na história destas disciplinas quanto ao arcabouço legal que então se instituía. Apesar de terem estado presentes de forma descontinuada em diversos momentos da educação brasileira e tendo experimentado um longo período de exclusão após a ditadura iniciada em 1964, resultando no seu total banimento no ano de 1971, pela primeira vez, tanto a disciplina de Filosofia quanto a de Sociologia estavam presentes de modo integral em uma etapa completa do ensino básico, concomitantemente. $\mathrm{O}$ simbolismo do fato histórico ganhava especial destaque por ter acontecido durante o governo de Luís Inácio Lula da Silva, na gestão de Fernando Haddad no Ministério da Educação: durante os dois mandatos presidenciais de Fernando Henrique Cardoso, sociólogo de formação e ex-aluno de Florestan Fernandes², 
a pressão da sociedade civil e de intelectuais da educação no sentido de aprovar a obrigatoriedade do ensino das duas disciplinas foi repetidamente rechaçada. Um dos luminares da política educacional do governo Fernando Henrique, o também sociólogo Simon Schwartzman declarou na ocasião:

Introduzir mais cursos obrigatórios é tornar os currículos mais rígidos e mais burocráticos, sem nenhuma garantia de que os alunos vão ganhar algo com isto. Por que sociologia e filosofia, e não economia, direito ou antropologia? Além do mais, como estas áreas são controversas, e a maioria dos cursos superiores brasileiros nestas áreas não são bons, o mais provável é que ensino acabe sendo dado por professores sem a mínima condição de transmitir aos alunos os conteúdos realmente ricos e interessantes que a filosofia e sociologia podem ter. A obrigatoriedade destas disciplinas foi uma vitória dos sindicatos de sociólogos e de professores de filosofia, que ganharam assim empregos garantidos para os que têm estes diplomas. Bom para eles, mas um retrocesso a mais no péssimo ensino médio que temos no país. (SCHWARTZMAN, 2007).

Por conta de sua promulgação, o presidente em exercício, José de Alencar declarou: "Precisamos dessas duas matérias para nos facilitar o exercício da democracia". Na mesma linha simplificadora, César Callegari, conselheiro do CNE declarou que a decisão estimularia os estudantes a desenvolverem o espírito crítico. "Isso significa uma aposta para que os alunos possam ter discernimento quando tomam decisões e que sejam 
tolerantes porque compreendem a origem das diversidades". Ambos reproduzem um fraseado de uso tão corrente que seu desgaste cumula seu próprio esvaziamento simbólico, facilmente absorvidos pelo senso comum em seu sentido ingênuo, acrítico, do pensamento enquanto instância incapaz de produzir significações complexas - o que torna uma atitude, ironicamente, radicalmente antifilosófica, mas perfeitamente ajustada a um sistema político cooptado por uma ideologia cuja estratégia de dominação utiliza-se perversamente do expediente da despolitização do debate público em todas as esferas possíveis, esterilizando significados em enunciados curtos e de aspecto puramente retórico. A este respeito, nos diz o professor Silvio Gallo:

Pensando especificamente no Ensino de Filosofia, há uma ideia que se generalizou dentre nós: aquela que afirma que a Filosofia desenvolve o "senso crítico" dos estudantes. Esse discurso foi central nas décadas de 1970 e 1980, na medida em que a luta pela inclusão da Filosofia nos currículos era parte da luta contra a ditadura. Porém, parece-me que essa posição é complicada. Por um lado, porque se a crítica é inerente à atividade filosófica, politicamente sabemos que, ao longo da história, se ela serviu para questionar os poderes instituídos, serviu também para garantir essa instituição. E por outro, porque se defendemos uma educação crítica, essa tarefa não pode ser exclusiva da Filosofia, mas precisa ser assumida por todas as disciplinas. (GALLO, 2011). 
Problematizando um pouco mais o debate, é possivelmente temerário pensar na introdução de qualquer disciplina como "solução" para os problemas da educação no Brasil. Porém, a má interpretação do texto da LDB, que define os currículos por áreas de conhecimento e não por disciplinas, permitiu pressões equivocadas e o lobby de diversos setores privados no sentido dessa excessiva "disciplinarização" da escola, levando a um inchaço do currículo. Esta concepção de escola, no limite, deverá algum dia resultar em especialidades infinitas, incomunicáveis, confinadas aos seus "50 minutos" semanais de exposição de conteúdos. Se os pareceres e resoluções do CNE que subsidiaram o retorno da Filosofia à escola recomendavam "carga horária suficiente para o seu adequado desenvolvimento", as secretarias estaduais, por seu turno, orientadas por resoluções locais modeladas por pressões de grupos privados organizados, preconizadores de modelos gerenciais de gestão na educação, dificilmente cumprem o texto legal. Até porque a recomendação de "carga horária suficiente" é uma definição que pode ser, com má fé, compreendida como imprecisa e interpretada ao sabor dos interesses de ocasião dos gestores públicos, quando afastados das pressões dos setores da sociedade civil com participação direta nas questões educacionais. Tanto a Filosofia quanto a Sociologia ficam costumeiramente relegadas a posições coadjuvantes nas grades de disciplinas na maioria dos estados da federação, com a carga horária reduzida ao mínimo em função da disputa com disciplinas como empreendedorismo e ensino religioso.

Para situar a discussão proposta acerca da introdução do caráter obrigatório do ensino de Filosofia no Brasil, optamos por estabelecer uma reflexão em torno de dois olhares sobre 
a Filosofia enquanto prática considerados marcos analíticos essenciais para interpretar politicamente os projetos em disputa no campo da educação em nossa sociedade nas recentes décadas como possibilidades de resistência diante das pressões hegemônicas transnacionais de caráter neoliberal. E para subsidiar tal reflexão, façamos, a título introdutório, uma breve narrativa sobre alguns dos papéis da Filosofia em seu percurso histórico como campo do saber:

Consideramos o ato de filosofar como uma atividade da razão. Uma variação da atividade racional tal e qual as demais ações não fisiológicas abrigadas no edifício da cultura em seu sentido mais amplo - i.e, o lugar tem início o humano e onde finda o natural. Desta feita, está separada em grau, não em gênero, de qualquer atividade manual ou intelectual que envolva uma mediação simbólica exercida historicamente pela espécie cognominada de Homo Sapiens Sapiens - não simplesmente o "homem que sabe", mas o "homem que sabe que sabe". A distinção deve servir para demarcar o estatuto ontológico da consciência frente ao da existência e tem também o papel de situar um campo específico, o da existência no tempo - que caracteriza o estado de consciência - inaugurando a história, a possibilidade de legar no tempo as marcas do agir no mundo e de pensar as possibilidades da existência a partir deste agir e de suas limitações. O agir humano passa a ser pensado em escala, cosmologicamente, do confronto entre as várias consciências contrapostas a partir da tensão inaugural do pensamento: confrontar a finitude tornada consciente com o desejo de tocar o infinito manifestado sob variadas formas, mas, sobretudo, na imaterialidade, no além do homem, no espaço que se coloca em princípio para além das categorias do pensamento especulativo. 
A história tradicional da filosofia nos aponta que o primeiro movimento desta razão foi na direção daquilo que conhecemos por pensamento religioso, manifesto nas inúmeras mitologias que buscavam dar conta de uma ordenação "primitiva" da realidade a partir das categorias de conhecimento compatíveis ao estágio civilizatório das primeiras sociedades humanas. A razão que se inaugura no percurso que a tradição convenciona legendar com "razão ocidental", de matriz helênica, esteve inicialmente vinculada ao esforço de traduzir a natureza por meio de uma narrativa cosmológica - rompendo com as determinações axiológicas características da narrativa mítica, profundamente hierarquizada (discurso de autoridade) e refratária ao exercício da reflexão que se funda na dúvida (dogmática). Aquiescer ao que propõe esta narrativa (hegemônica) implica pressupor que a filosofia, strictu sensu, nasce por volta do século VI a.c., na região mediterrânea da Jônia. Implica em uma dissensão entre um "pensar" alegadamente assistemático, não rigoroso, pré-crítico e outro, de natureza sistemática, rigorosa, crítica, ou seja, "filosófico".

Esta philia, esta disposição do espírito é de caráter fundante para o exercício de uma atividade interessada apenas no conhecimento per se e, por extensão, na recusa radical de qualquer inversão valorativa que trouxesse para o limiar da investigação dita filosófica o desejo de auferir ganhos de outra natureza senão a própria recompensa da "busca pelo saber" que se empreende. Esta asserção torna-se mais facilmente verificável nos embates teóricos do período clássico, mormente nos diálogos platônicos que registram veemente censura ao modelo filosófico empreendido pela escola sofística. A filosofia, esta atividade desinteressada, filha do "espanto" e 
da curiosidade, torna-se "filosofia" apenas quando adequada a uma normatização instrumental, capaz de fazê-la distinta das demais atividades do pensamento humano, para não se confundir com as artes, com a religião, com as protociências e com o engenho humano em geral.

Buscando cada vez mais esta distinção, a filosofia antiga em seu período antropológico desenha seu curso sobre uma calha metafísica. O dualismo platônico, ao estipular o campo da filosofia como o da busca epistêmica, abre o fosso que torna o fazer filosófico uma atividade de poucos e para poucos, característica daqueles que "ousam" empreender por meio da crítica a atividade de partejar conceitos, sem ter-lhe facultado o direito ao uso de "anestésicos" (as ilusões dos sentidos, o "aprisionamento da vida material") nem o recurso a métodos alternativos ao "parto natural". A imagem épica do filósofo como o indivíduo que rompe os grilhões da doxa e se atira ao mundo corajosamente na busca da elevação por meio do emprego da racionalidade torna-se, paradoxalmente, um mito fundador do modelo civilizatório que grassou na tradição ocidental e empresta ao fazer filosófico um caráter eminentemente aristocrático. Na teoria política platônica, ao destemido "filósofo" caberia a tarefa de conduzir, tornar-se prócer, iluminar as massas aprisionadas à doxa.

Uma das imagens utilizadas por Sócrates para descrever sua atividade é o de "parteiro de ideias", em alusão ao método conhecido por maiêutica, herdado da atividade profissional de sua mãe, Fenarete, conforme nos é narrado por Platão no diálogo Teeteto. A atitude "generosa" de eleger interlocutores indistintamente, muito mais interessada no propósito dialético de "dar à luz" ao conceito, elide na aparente horizontalidade 
relacional uma epistemologia ainda profundamente hierarquizada, explicitada por Platão em sua metafísica. A doxa nutre a episteme durante toda a gestação do conceito. Porém, ao nascer, a primeira é imediatamente separada da segunda e tratada como refugo, tal e qual o envoltório placentário em relação ao nascituro. Não se trata aqui de fazer um elogio do senso comum, mas sim de reconhecer sua importância na formação do pensamento filosófico, uma espécie de "chão comum" ou "ponto de partida", essencial para a filosofia como própria condição de possibilidade.

Antonio Gramsci lança luz sobre esta questão ao reabilitar o senso comum elevando todos os homens à categoria de filósofos, situando a filosofia em terrenos mais amplos que o da tradicional ratio fundada pelos helênicos em contraposição às narrativas mitológicas. Gramsci traz para os campos da linguagem, da religião e da cultura como os campos fundadores da filosofia, ampliando, por conseguinte, os limites conceituais do próprio "fazer filosófico" alterando seu caráter distintivo, seu "selo de origem". A filosofia passa a ser uma marca do agir humano em um sentido agora verdadeiramente universal - nada mais apropriado para um pensamento que se pretende reformador. Vemos sem prejuízo para o conceito um movimento de "vulgarização" da filosofia, no sentido primeiro de "para o povo", coerentemente ao sistema teórico-político fundado no papel dos intelectuais para o fortalecimento de hegemonias alternativas ao modelo dominante, como nos aparece no seguinte trecho:

É preciso, portanto, demonstrar preliminarmente que todos os homens são 'filósofos', definindo os limites e 
as características desta 'filosofia espontânea', peculiar a 'todo o mundo', isto é, da filosofia que está contida: 1) na própria linguagem, que é um conjunto de noções e de conceitos determinados e não, simplesmente, de palavras gramaticalmente vazias de conteúdo; 2) no senso comum e no bom senso; 3 ) na religião popular e, consequentemente, em todo o sistema de crenças, superstições, opiniões, modos de ver e de agir que se manifestam naquilo que geralmente se conhece por 'folclore'. (GRAMSCI, 1999, vol. 1, p.93).

A pressuposição de que determinados homens são naturalmente mais ou menos inclinados à atividade filosófica atua de modo inocente ou intencional no sentido de sustentar uma ordem que se baseia na produção do consenso em um caminho contrário ao de uma sociedade igualitária. Pensar a filosofia apenas como um saber altamente especializado tem como contraefeito investir-lhe um manto de hermetismo, operando no sentido da construção de uma sociedade antiigualitária. Ao contrário do que se pode supor, não se trata de uma visão romântica ou ingênua supor que todo homem é filosofo. Trata-se, sim, de uma visão coerente com todo o sistema teórico que Gramsci produziu, correlato à sua filosofia da práxis, que reposiciona a filosofia no terreno da mediação simbólica exercida pela linguagem ordinária que faz do homem ator consciente no campo da realidade natural. Não há dicotomia entre a ação prática e a reflexão. Ambos se constituem continuamente. A separação em grau entre o senso comum e o bom senso se dá pelo esforço de superar a adesão a um determinado ponto de vista por conta 
dos obstáculos iniciais que caracterizam os preconceitos que acomodam os indivíduos em função das posições que ocupam dentro da sociedade, sobretudo o conforto do pertencimento - por classe, por etnia, por geração, por nacionalidade, por religiosidade ou por demais fatores culturais, como exposto no trecho em destaque:

Após demonstrar que todos são filósofos, ainda que a seu modo, inconscientemente - já que, até mesmo na mais simples manifestação de uma atividade intelectual qualquer, na 'linguagem', está contida uma determinada concepção do mundo, passa-se ao segundo momento, ao momento da crítica e da consciência, ou seja, ao seguinte problema: é preferível 'pensar' sem disto ter consciência crítica, de uma maneira desagregada e ocasional, isto é, 'participar' de uma concepção do mundo 'imposta' mecanicamente pelo ambiente exterior, ou seja, por um dos muitos grupos sociais nos quais todos estão automaticamente envolvidos desde sua entrada no mundo consciente (e que pode ser a própria aldeia ou a província, pode se originar na paróquia e na 'atividade intelectual' do vigário ou do velho patriarca, cuja 'sabedoria' dita leis, na mulher que herdou a sabedoria das bruxas ou no pequeno intelectual avinagrado pela própria estupidez e pela impotência para a ação), ou é preferível elaborar a própria concepção do mundo de uma maneira consciente e crítica e, portanto, em ligação com este trabalho do próprio cérebro, escolher a própria esfera de atividade, participar ativamente na produção da história do mundo, ser o guia de si mesmo e não mais aceitar do exterior, passiva e servilmente, a marca da própria personalidade? (GRAMSCI, 1999, vol. 1, p.93). 
Gramsci nos chama atenção para o fato de que não há possibilidade nenhuma de estarmos completamente a salvo destes preconceitos - exceto pela via do autoengano - dos quais a filosofia moderna procurou nos "livrar" a partir de uma "assepsia metodológica" que procurava através de uma espécie de "certificado de origem" assegurar a possibilidade humana de produzir conhecimento cientificamente válido. Ver o filósofo no homem ordinário é uma operação necessária para tornar possível a realização de um projeto de sociedade permeável ao novo para tornar o indivíduo sensível a este novo, conferindo-lhe "condutibilidade" na relação com os intelectuais especializados. Negar esta possibilidade é afirmar a manutenção das estruturas que perpetuam a desigualdade. O conceito gramsciano de filosofia, em vez de pretender liberar o ser humano da caverna, despoja o filósofo do lugar "amigo privilegiado do saber" para fazê-lo próximo dos outros homens.

Não ressoa impróprio afirmar que o conceito amplo de "filósofo" que Gramsci utiliza pode valer-se da base racional aristotélica para explicar seu funcionamento. Todo homem carrega em si a potência de todas as atividades humanas, cuja realização em ato dependerá da ação conjunta das causas analiticamente descritas em sua metafísica (formal, eficiente, material e final). A habilidade manual pouco ordinária permite ao homem comum, por exemplo, a capacidade de fixar um prego à parede sem grande esforço. A habilidade desenvolvida o faria profissional de marcenaria ou carpintaria, à guisa de exemplo. O mesmo ocorreria com o fazer filosófico, grosso modo, ou para ser mais específico, com a atividade intelectual de maneira geral. Ao perceber nos 
vestígios de tradições anteriores ao seu tempo ideias advindas de sistemas filosóficos arcaicos - seja na religião, na cultura popular e sobretudo na linguagem, que Gramsci situa como condição de possibilidade para o exercício pleno da filosofia (cabe aqui indicar o trabalho do filósofo estadunidense Richard Rorty sobre a linguagem com o uso de "metáforas mortas", sendo que a metáfora tão presente nas mitologias acaba sendo ao fim do seu turno um elemento fundador e objeto da própria filosofia - eis aqui a ironia da razão que se pretende soberana, pura). Por esta razão Gramsci nos chama a atenção para o fato de que quanto maior a extensão lexical de um idioma, mais elevadas as possibilidades do exercício da filosofia, dada a maior possibilidade de variações conceituais e de categorias de pensamento aplicáveis ao movimento de apreensão descritiva do real. Segundo ele:

Pela própria concepção do mundo, pertencemos sempre a um determinado grupo, precisamente o de todos os elementos sociais que compartilham um mesmo modo de pensar e de agir. Somos conformistas de algum conformismo, somos sempre homens-massa ou homens-coletivos. O problema é o seguinte: qual é o tipo histórico de conformismo, de homem-massa do qual fazemos parte? Quando a concepção do mundo não é crítica e coerente, mas ocasional e desagregada, pertencemos simultaneamente a uma multiplicidade de homens-massa, nossa própria personalidade é compósita, de uma maneira bizarra: nela se encontram elementos dos homens das cavernas e princípios da ciência mais moderna e progressista, preconceitos de todas as fases históricas passadas estreitamente 
localistas e intuições de uma futura filosofia que será própria do gênero humano mundialmente unificado. (GRAMSCI, 1999, vol. 1, p.93).

Com boa dose de ironia, Descartes, talvez considerando o senso comum um espaço distinto do espaço da falta de bom senso (que consistiria na dificuldade em inferir logicamente ou de aduzir coerentemente pela observação do real), afirmou que "o bom senso é a coisa do mundo mais bem distribuída: todos pensamos tê-lo em tal medida que até os mais difíceis de contentar nas outras coisas não costumam desejar mais bom senso do que aquele que têm" (1983, p. 5). A reflexão gramsciana não pretendia contemplar o estabelecimento de uma empresa filosófica que ambicionasse refundar a metafísica ocidental limpando o terreno da ciência, devastado pelo ceticismo que marca o fim da idade média, como no caso do pensador francês. Gramsci, intelectualmente situado no campo do materialismo histórico, pretende oferecer uma perspectiva do "bom senso" muito mais cara à filosofia política, acenando com uma possibilidade real de que o bom senso não se trata de uma recompensa duvidosa ao fim de uma escalada fatigante por uma elevação íngreme e acidentada. O bom senso seria o núcleo sadio do senso comum, elemento comum a todos os indivíduos, mesmo quando não têm consciência de terem problemas filosóficos.

Gramsci propõe um conceito amplo de filosofia e esta abertura tem um papel estratégico para o sistema que nos propõe de disputa por hegemonia. As definições de filosofia têm sido tão controversas para a própria filosofia que chegar a afirmar que todos os homens são filósofos não 
constitui nenhuma irresponsabilidade. A questão é em qual enquadramento, sobre qual filosofia se fala quando se pretende fazer caber sob ela toda a racionalidade. O sentido que nos propõe Gramsci é o mais amplo possível, quase esgarçado, no limite da ruptura. Gramsci, neste aspecto, se vê ombreado com o positivista lógico Karl Popper, ao esfumaçar a fronteira entre filosofia e senso comum, estando o segundo mais próximo a uma epistemologia crítica; enquanto o primeiro, às condições de possibilidade da sua filosofia da práxis. O movimento desejado através da crítica é o de afastamento do circunstancial, do tempo presente. É o movimento de compreensão do histórico, do processual, das questões estruturais e estruturantes do mundo dos homens. Deste estranhamento inicial é que se torna possível lançar as bases de uma atividade filosófica rigorosa e sistemática que caracteriza o labor do intelectual especializado, uma vez que nada em filosofia se constitui original e é no próprio campo da linguagem que se desfazem e se reinterpretam os nós que constituem os problemas com os quais ela se depara e diante dos quais se interpõe em posição interpretativa, como nos aponta novamente Gramsci:

Criticar a própria concepção do mundo, portanto, significa torná-la unitária e coerente e elevá-la até o ponto atingido pelo pensamento mundial mais evoluído. Significa também, portanto, criticar toda a filosofia até hoje existente, na medida em que ela deixou estratificações consolidadas na filosofia popular. $\mathrm{O}$ início da elaboração crítica é a consciência daquilo que é realmente, isto é, um 'conhece-te a ti mesmo' como produto do processo histórico até hoje desenvolvido, 
que deixou em ti uma infinidade de traços acolhidos sem análise crítica. Deve-se fazer, inicialmente, essa análise. (GRAMSCI, 1999, vol. 1, p.93).

Chegamos à compreensão de que a ideia de senso comum igualada à ideia de "chão comum" ou de "norte comum" no enquadramento destacado neste artigo pode servir conceitualmente para a interpretação das funções da escola e da filosofia, para além de seu campo disciplinar específico, comunicando-se com um ideal pedagógico que tenha a Práxis como pedra angular do processo relacional indivíduo-sociedade. A última citação em destaque aponta para a formação do indivíduo a partir "nosce te ipsum" em um sentido agora muito mais encarnado e humano que em sua matriz socrático-platônica. Falamos em um significado cindido pela "afetação" das massas tornada possível a partir da ação de intelectuais comprometidos com a construção de uma "contra-hegemonia". Esta difusão nada mais seria que a ação do indivíduo como retransmissor, variando em grau de "sensibilização". Do "homem-massa" ao "intelectual orgânico" novamente haveria a separação por grau, não por gênero, segundo Gramsci:

[...]todo grupo social, ao mesmo tempo em que se constitui sobre a base original da função essencial que ele assume no campo da produção econômica, cria organicamente uma ou mais camadas intelectuais que lhe asseguram homogeneidade e consciência de sua própria função, não somente no setor econômico, mas também nos setores social e político [...] (GRAMSCI, 1999, vol. 1, p.125). 
Desta feita, o intelectual orgânico funcionaria como um elemento de difusão, em uma metáfora que interpreta o "homem-massa" em analogia a pulsos elétricos de maior ou menor amperagem, segundo o amadurecimento crítico por eles vivenciado, fazendo a "energia" de transformação social circular gradativamente em maior amplitude e maior força, conforme o sucesso do projeto político delineado em sua "Práxis". A ampliação da "condutibilidade" é a própria condição de possibilidade de propagação dos valores contra-hegemônicos. Tal ampliação deveria por fim emanar-se até produzir as transformações esperadas na realidade segundo o conceito de "bloco histórico" (conjunto complexo e contraditório, onde a superestrutura é o reflexo do conjunto das relações sociais de produção compreendido em sua expressão concreta, histórica). Esta ampliação visaria alcançar a participação dos entes sociopolíticos descritos como "intelectuais tradicionais", egressos da elite culta, que viriam a atuar in tempore conforme a ação política dos intelectuais orgânicos, segundo sua disputa por hegemonia até o momento da dissolução da distinção entre saberes e fazeres outrora hierarquizados pela oposição "populares versus eruditos" enquanto manifestações fundamentais do sectarismo que mantém ordenado o sistema desigual de distribuição de bens materiais e imateriais na sociedade de consumo. A passagem abaixo ilustra bem esta definição:

No momento da crise do 'bloco velho', burguesia e proletariado disputam a aliança dos intelectuais tradicionais, cuja adesão torna-se possível e ocorre 'espontaneamente' nos momentos em que um grupo 
social determinado aparece como historicamente progressista, isto é, quando ele promove os interesses da sociedade como um todo, não somente satisfazendo suas exigências fundamentais, mas também ampliando progressivamente seus próprios quadros, através da conquista constante de novas esferas de atividades econômico-produtivas. (GRAMSCI apud MACHIOCCHI, 1982, p. 195):

Já Paulo Freire atualiza o conceito de conscientização com o sentido de aquisição de uma visão libertadora da realidade (aqui entendida no sentido de pedagogia da libertação ou pedagogia da autonomia), com o objetivo de permitir aos oprimidos a reversão de sua condição, relacionando essa tomada de consciência a uma ação política e educativa a um só tempo, uma concepção libertadora da educação. Essa práxis é considerada libertadora pela finalidade de ir até à raiz dos processos de opressão. Essa leitura da realidade, análoga à dialética do senhor e do escravo presente em Hegel, tem por objetivo oferecer ao oprimido a possibilidade de lutar contra os processos que engendram sua condição e tornar-se criador de uma nova realidade. Tida como sua maior obra "A Pedagogia do Oprimido" é sobretudo o caminho de um fazer-se humano, uma vez que a opressão é uma ação que funciona no sentido da desumanização, da negação da identidade, pela via da negação dos direitos fundamentais da pessoa e de seu reconhecimento social.

Gramsci percebeu a importância dos aspectos políticos e culturais para a transformação da sociedade, para além do 
determinismo histórico-econômico da tradição marxista, enfatizando a transformação filosófica, política e cultural na sociedade civil como caminho para disputar o poder. Freire, assim como Gramsci, percebe essa potencialidade de organização da sociedade civil, fazendo-se valer de todas as instituições capazes de influenciar a população, não se limitando à escola, pensando a construção da autonomia dos indivíduos coletivamente constituídos em uma práxis político-pedagógica contra-hegemônica. Segundo Freire,

Quem, melhor que os oprimidos, se encontrará preparado para entender o significado terrível de uma sociedade opressora? Quem sentirá, melhor que eles, os efeitos da opressão? Quem, mais que eles, para ir compreendendo a necessidade da libertação? Libertação a que não chegarão pelo acaso, mas pela práxis de sua busca; pelo conhecimento e reconhecimento da necessidade de lutar por ela. Luta que, pela finalidade que lhe derem os oprimidos, será um ato de amor, com o qual se oporão ao desamor contido na violência dos opressores, até mesmo quando esta se revista da falsa generosidade referida. (FREIRE, 1970, P.17).

Ligada ao movimento da Teologia da Libertação, a práxis freireana também é mais do que a de um humanismo cristão: constitui-se em um humanismo radical, porque se realiza pela fé no homem e não na salvação. Realizar a potência transformadora do homem é um projeto que nasce, sobretudo da crença radical na capacidade do homem recriar-se e de recriar a realidade à sua volta. E é possivelmente neste aspecto que a Filosofia laica de Gramsci 
e a confessional de Freire se encontram. Em suas próprias palavras, "estudar não é um ato de consumir ideias, mas de criá-las e recriá-las". Ao pensar o Cristo na sua radicalidade humana, pode-se ver, não a ponte para uma redenção mística, mas para um encontro concreto com um projeto de origem que é a marca da criação: ao fazer-se consciente, ao tornar-se apto a ler o mundo, a potência que se realiza é a potência divina (criador) no homem (criatura). Fazerse imagem e semelhança de Deus neste caso ocorre a partir do reconhecimento de si em relação ao mundo e aos outros. A consciência crítica é a realização humana do projeto "divino": ou seja, ser semelhante a Deus é criar, não obedecer. O crítico é o transgressor. O transformador é o que rejeita a ordem e a recria a partir de sua experiência material, concreta.

Cristo é uma figura universal. Freire percebeu como sendo mais fértil propor a transformação política a partir de uma apropriação catequética do pensamento cristão, que procurar a transformação da estrutura da sociedade a partir da negação da religião. Encontrar-se com o cristianismo do ponto de vista da ação de um intelectual contra-hegemônico tem uma profunda imbricação com a conjuntura histórica da década de 60, que a partir da experiência da teologia da libertação, viu surgir, pelo mundo em geral, e pela América Latina em particular, a possibilidade real de uma alteração na correlação das forças em disputa no cenário político, graças ao seu poder de mobilização junto às massas. E foi pela autenticidade do pathos que lhe animava a ação política, que esta teve a potência inspiradora e o alcance ainda hoje pulsantemente vivos. 
Fosse a adoção da via teológica um mero recurso estratégico de aproximação com as massas, seu modelo de intervenção não lograria permanência nem alcance. Seu modelo de humanismo é revolucionário, porque reúne ação educativa à ação política. O conceito de autonomia, para além do projeto iluminista, ganha em Paulo Freire uma atualização do compromisso gramsciano que remete ao pensamento marxista da ação engajada, da relação indissociável entre pensamento e ação.

Ao endossar a fé como caminho e não como obstáculo para a consecução deste ideal transformador, ele atualiza Gramsci, ao entender que a mudança da estrutura não é possível sem conceber o potencial de todo homem como filósofo. E atualiza Marx, ao dizer que ao filósofo cabe transformar e não meramente pensar o mundo. Sua ideia de Cristo é a de um Cristo radicalmente humano, dialético (concebendo a ideia do humano como o ontologicamente histórico, contraditório) e portador de uma mensagem de natureza profundamente política. Após este percurso teórico, podemos aqui retomar a discussão do marco legal que discorre sobre a regulamentação do ensino de Filosofia no Brasil.

A Filosofia enquanto caminho de formação humana, enquanto via de realização da construção das potencialidades humanas, presente de forma marcante nas obras de Gramsci - que tem por base o respeito ao conceito de uma Filosofia espontânea, diante das condições estruturais da educação brasileira, corre o risco de tornar-se uma Filosofia anêmica, instrumentalizada, refugo de um projeto de escola, ora vista como assunto de difícil penetração. Ou seja, se estivermos 
buscando pensar a partir de uma matriz freireana ou gramsciana de educação, o sentido da Filosofia enquanto componente curricular apareceria complementarmente a um projeto que tem a Filosofia como prática permanente, como atitude diante da realidade, como condição de transformação política do mundo e como fundamento da própria ação pedagógica. Não seria uma "supradisciplina", tampouco uma disciplina entre disciplinas, mas sim, o próprio substrato humanizador, elemento fundante do pensamento e da cultura, pela via da palavra, enquanto instância primordial da humanização. A Filosofia disciplinar, sem o devido cuidado, poderia facilmente tornar-se mais uma ferramenta bancária. Sobretudo em um modelo de sociedade pautado pela ideologia do consumo conspícuo.

Em verdade, é novamente temerário avaliar o êxito do intuito legal de fomentar a ampliação da capacidade crítica dos educandos, por meio da introdução da Filosofia na grade obrigatória do ensino médio - por carência de fundamentação empírica e pelo fato óbvio da criticidade não ser um objeto dado a aferições - o que não nos obriga a assumir um paradigma positivista de reflexão. Mas há elementos claros que apontam para o sucateamento contínuo da escola pública e do incessante projeto de perpetuála enquanto uma máquina produtora de desigualdades, perfeitamente funcional ao nosso modelo de integração ao capital-imperialismo. Trazer a Filosofia para a escola dentro destas condições pode, talvez, significar no máximo reduzir sua função ao campo estético: uma beleza que não transforma. O pensamento reduzido à forma ou um saber fetichizado, a glória da educação bancária. A esterilização 
em massa do potencial transformador que se processa em cada âmbito humano: do profissional, ao artístico, ao afetivo, ao político. Segundo Freire,

A narração, de que o educador é o sujeito, conduz os educandos à memorização mecânica do conteúdo narrado. Mais ainda, a narração os transforma em "vasilhas", em recipientes a serem enchidos pelo educador. Quanto mais vai se enchendo os recipientes, com seus "depósitos", tanto melhor educador será. Quanto mais se deixem docilmente encher, tanto melhores educandos serão. Em lugar de comunicarse, o educador faz "comunicados" e depósitos que os educandos, meras incidências, recebem pacientemente, memorizam e repetem. Eis aí a concepção "bancária" da educação, em que a única margem de ação que se oferece aos educandos é a de receberem os depósitos, guardálos e arquiva-los. Na visão "bancária" da educação, o "saber"é uma doação dos que se julgam sábios aos que julgam nada saber. Doação que se funda numa das manifestações instrumentais de ideologia da opressão - a absolutização da ignorância, que constitui o que chamamos de alienação da ignorância, segundo a qual esta se encontra sempre no outro. (FREIRE, (1970, p. 33).

A Filosofia passa a fazer figuração em uma escola com cada vez menos sentido, espremida dentro das engrenagens da máquina tecnocrática. A atuação docente, segundo a pedagogia freireana, deve estar atenta para o risco tanto da prática irrefletida, que se reduz a mero ativismo, quanto da reflexão sem prática, que se reduz ao formalismo infecundo, 
à estetização da racionalidade. E o formalismo também pode redundar no cumprimento da rotina burocrática do trabalho como aspecto fundamental da atividade docente, dando muito mais ênfase às chamadas, às notas, aos conselhos de classe que ao processo educativo em si. Este tipo de postura resulta como processo de conformação, caro ao docente que também tem seu trabalho precarizado, explorado. É mais fácil tornar-se opressor a partir das ferramentas concedidas pelo estado e reproduzir a opressão, que se envolver profundamente no compromisso ético de educar, escondendo-se atrás de responsabilidades numéricas e não políticas.

Sendo assim, a institucionalização à base do "canetaço" ainda remete à nossa histórica inclinação ao mandonismo. Uma vez reduzida à sua mera aparência, a Filosofia tornase peça secundária na estrutura curricular, elemento coadjuvante do processo bancário de educação que se fortaleceu ainda mais no período da onda neoliberal e da globalização. Crer que a introdução da Filosofia como componente curricular seja suficiente para proporcionar aos educandos formação crítica sólida e elementos consistentes para sua emancipação, formação política e para a cidadania, carrega grau de ingenuidade similar ao da crença de que a Lei Áurea bastaria para resolver a questão do negro no Brasil.

O modo procrastinador pelo qual lidamos com o espólio dos anos ditatoriais nos impediram de perceber (coletivamente) o quanto estávamos ainda imersos em um sistema predominantemente antirrepublicano, com a prevalência do interesse privado sobre o interesse público; 
um sistema herdeiro de relações e estruturas de poder semeadas desde o tempo do Brasil colônia. Descobrimos, pouco a pouco, o quanto vivemos em uma democracia asfixiada, parcial. Talvez um passivo originário do processo de distensão "lento e gradual" e incompleto - porque consagrou a impunidade de crimes imprescritíveis. Sem a profunda revisão de um projeto societário que passa necessariamente pela ideia de democracia que desejamos para nós enquanto país, a disciplina seguirá sendo um dos adornos das "prateleiras da perfumaria", tendo seu caráter de saber elitizado, reverenciado, distante dos ideais transformadores necessários para a Filosofia, na visão de Antonio Gramsci e de Paulo Freire. Ocorre que há um distanciamento, um fosso, uma perda crucial de contato entre os intelectuais contra-hegemônicos e as massas. $\mathrm{O}$ conceito de estado ampliado limita ainda mais esta disputa, uma vez que a estratégia ideológica de esvaziamento da esfera pública faz da escola um espaço esterilizado para o debate político, máquina onde se constroem valores opostos aos da democracia, construídos sobre uma cultura de silêncio e passividade, porque não há uma percepção coletiva de apropriação do espaço para além da esfera privada.

Nesse sentido, percebemos um afastamento claro entre o pensamento escolanovista e o de Paulo Freire. Pensar o potencial transformador da Filosofia o levava para muito além do espaço da escola. E pensar a Filosofia, segundo o pensamento de Antonio Gramsci e Paulo Freire, significa pensar também para além da função especializada do docente de Filosofia em sua limitação disciplinar - o que 
não significa que sua presença na escola seja desnecessária. Se é verdade que sua presença está longe de ser condição suficiente de transformação da realidade educacional e societária do país, também é verdade que não seria por sua ausência que teríamos efeito inverso. O que devemos atentar é para os riscos de conformação, de apassivamento, de crer ingenuamente que basta a presença soberana da Filosofia na estrutura curricular da escola para que a transformação se produza, ato contínuo. Sem representar um poder subversivo, sem contaminar todos os campos disciplinares com sua insubordinação, com seu destemor à dúvida, ao questionamento, à produção de conceitos, à humanização como valor universal, a Filosofia perde a alma e passa a ser parte do jogo.

Nesse sentido, cabe ao professor assumir para si o papel de agente processador desta transformação e levar adiante a missão de educar com cada vez maior consciência acerca do caráter político deste ato. Desta feita, Paulo Freire que propôs alternativas de ação pedagógica fora da escola para promover seu ideal de educação popular, provavelmente enxergaria com restrições o alcance da Filosofia enquanto disciplina escolar, em sintonia com o ideal de transformação social defendido por Gramsci, sem perceber na figura do professor de Filosofia qualquer primazia no sentido de conduzir o projeto de conscientização dos oprimidos - por não entender a Filosofia como matéria exclusiva de um segmento da atuação docente. O professor de Filosofia pode - e deve - ser aqui entendido como mais um dos agentes de transformação, em igualdade política e intelectual aos demais profissionais da educação. Para 
tanto, é fundamental para o educador compreender a importância da desconstrução do mito da neutralidade e reforçar a visão da ação educativa enquanto ação política, como aponta Freire (1996, p.70), "Que é mesmo a minha neutralidade senão a maneira cômoda, talvez, mas hipócrita, de esconder minha opção ou meu medo de acusar a injustiça? Lavar as mãos em face da opressão é reforçar o poder do opressor, é optar por ele".

Mais importante que sua inserção na matriz curricular obrigatória é a ampliação dos espaços que permitam a ação contínua das práticas de construção de autonomia, o que significa levar adiante o projeto de quebra das condições de opressão e reprodução das desigualdades presentes historicamente em nossa estrutura social, dentro e para além dos muros da escola.

\section{NOTAS}

${ }^{1}$ Doutorando em Educação pela Universidade Federal Fluminense (UFF). E-mail: reinaldoramos@id.uff.br.

${ }^{2}$ As menções à Fernando Henrique Cardoso e Florestan Fernandes não se devem apenas ao fato de serem ambos não casualmente oriundos do campo das Ciências Sociais, mas sobretudo por serem também intelectuais de incontestável referência na formação do pensamento político e sociológico brasileiro contemporâneo. 


\section{REFERÊNCIAS}

BRASIL. Lei $n^{\circ}$ 9394/96. Estabelece as diretrizes e bases da educação nacional. Disponível em http://www.planalto. gov.br/ccivil_03/LEIS/L9394.htm\#art36\$1iii (acessado em 18/07/2014).

BRASIL. Lei $n^{\circ} 11684 / 2008$. Altera o art. 36 da Lei no 9.394, de 20 de dezembro de 1996, que estabelece as diretrizes e bases da educação nacional, para incluir a Filosofia e a Sociologia como disciplinas obrigatórias nos currículos do ensino médio. Disponível em: www.planalto.gov.br/ ccivil_03/_Ato2007-2010/2008/Lei/L11684.htm (acessado em 18/07/2014).

BRASIL. Ministério da Educação. Conselho Nacional da Educação/Câmara da de Educação Básica. Parecer CNE/CEB $n^{\circ} 22 / 2008$, aprovado em 8 de outubro de 2008. Do parecer sobre a inclusão obrigatória das disciplinas de Filosofia e Sociologia no currículo do Ensino Médio. Disponível em: http://portal. mec.gov.br/cne/arquivos/pdf/2008/pceb022_08.pdf (acessado em 19/07/2014).

BRASIL. Ministério da Educação. Conselho Nacional de Educação/Câmara de Educação Básica.Resolução $n^{\circ} 1$ de 15 de maio de 2009. Dispõe sobre a implementação da Filosofia e da Sociologia no currículo do Ensino Médio, a partir da edição da Lei $n^{\circ} 11.684 / 2008$, que alterou a Lei $\mathrm{n}^{\circ}$ 9.394/1996, de diretrizes e Bases da Educação Nacional (LDB). Disponível em: http://portal.mec.gov.br/ dmdocuments/resolucao_cne_ceb001_2009.pdf (acessado em 19/07/2014). 
BRASIL. Ministério da Educação. Conselho Nacional de Educação/Câmara de Educação Básica. Resolução $n^{\circ} 4$, de agosto de 2006. Altera o artigo 10 da Resolução CNE/CEB no 3/98, que institui as Diretrizes Curriculares Nacionais para o Ensino Médio. Disponível em: http://portal.mec.gov.br/cne/ arquivos/pdf/rceb04_06.pdf (acessado em 19/07/2014).

COUTINHO, Carlos Nelson. De Rousseau a Gramsci. São Paulo: Boitempo, 2011.

COUTINHO, Carlos Nelson. Cultura e Sociedade no Brasil. Ensaios Sobre Idéias e Formas. Rio de Janeiro: DP\&A, 2000.

DESCARTES, R. Discurso do Método; Meditações; trad. Bento Prado Jr. e J. Guinsburg. — São Paulo: Abril Cultural, 1983.

DANTAS, R. Filosofia, educação e história. In: KOHAN, W. (Org.). Ensino de filosofia: perspectivas. Belo Horizonte: Autêntica, 2002.

FREIRE, P. Pedagogia da autonomia: saberes necessários à prática educativa. São Paulo: Paz e Terra, 1996.

FREIRE, P. Pedagogia do Oprimido. São Paulo: Paz e Terra, 1970.

FREIRE, P. Cartas à Guiné Bissau. São Paulo: Paz e Terra, 1978.

GALLO, S. http://filescola.blogspot.com.br/2011_10_01_archive. html. Campinas, 2011.

GRAMSCI, A.Cadernos do Cárcere, volume 2; edição e tradução Carlos Nelson Coutinho; co-edição, Luiz Sérgio Henriques e 
Marco Aurélio Nogueira. Rio de Janeiro: Civilização Brasileira, Civilização Brasileira, 1999.

MACCIOCHI, M. H. A Favor de Gramsci. Rio de Janeiro: Paz e Terra; 1982.

MARX, K.; ENGELS, F. A Ideologia Alemã, São Paulo: Martins Fontes, 1998.

REALE, G. História da Filosofia Antiga: II Platão e Aristóteles. Tradução Henrique Cláudio de Lima Vaz e Marcelo Perine. São Paulo: Loyola, 1994.

REALE, G. Pré-Socráticos e Orfismo. Tradução Henrique Cláudio de Lima Vaz e Marcelo Perine. São Paulo: Loyola, 1994.

POPPER, K. Em Busca \& um Mundo Melhor. Lisboa: Ed. Fragmentos, 1989.

RORTY, R. A Filosofia e o Espelho da Natureza. Tradução Antonio Trânsito; revisão César Ribeiro de Almeida. Rio de Janeiro: Relume-Dumará, 1995. p.193.

SCHWARTZMAN, A Obrigação de Ensinar Filosofia e Sociologia na Escola. Disponível em: http://alias. estadao.com.br/noticias/geral,introduzir-mais-cursose-tornar-os-curriculos-mais-rigidos-e-burocraticos. Busca em: 19/07/2014. 